\title{
Long Run and Short Run Linkages Between Credit and Output:
} \section{An Appraisal of the Districts of West Bengal in India}

\author{
Ramesh Chandra Das, Vidyasagar University, India \\ Bankim Ghosh, Katwa College, India
}

\begin{abstract}
An appropriate link between the financial sector and real sector is required to have a balanced growth and development of a country as well as its regional levels particularly for the countries whose financial developments are not being saturated. In the present study, the authors have examined whether there are long run equilibrium relation between financial development (proxied by commercial bank credit) and real sector's development (proxied by net district domestic products) and short run causations for the districts of the state of West Bengal in India for the period 1993-2014. Applying the EngelGranger cointegration and Granger causality approaches, the study reveals that there are cointegrating relations between credit and domestic products of the 13 districts out of which errors are corrected for 10 districts. Further, there are unilateral causal relations between the variables in nine districts with 11 producing no such causal relations. The study thus prescribes for strengthening the two sectors' developments so that there can be appropriate linkages between credit and output across the district levels in the longer runs.
\end{abstract}

\section{KEYWORDS}

Cointegration, Credit, Districts, Granger Causality, Net District Domestic Product, Unit Root

\section{INTRODUCTION}

Whether financial institutions do have any significant impact on the real sectors of the economy has been the subject of discussion and debate among the economists of different schools. Adam Smith (1789) did not believe that the financial institutions have any influence upon the production activities of the real sectors and so growth of a nation. Smith, in his famous book, "Wealth of Nation" has pointed out that farmers, producers and businessmen are the important carrier of economic growth. To him, roles of business enterprises, competition and free trade would be to lead the farmers, producers and businessmen to expand market size and which, in turn, would stimulate economic development. Schumpeter (1911), on the other hand, postulated the reverse argument. According to him, economies make progress through the trade cycle in a dynamic and discontinuous system. In order to break the circular flow the workings of the innovative entrepreneurs are to be financed by banking funds. Therefore, bank credit can have great impact on the growth of the real sectors of the economy. In another work, Schumpeter (1934) highlighted the importance of financial intermediaries in mobilizing savings, evaluating projects, diversifying risks, monitoring management of firms in debt, and facilitating transactions which are essential for innovation and economic growth. Patrick 
(1966) is probably the first to clearly define the one-to-one correspondence between bank credit and growth of aggregate output, especially for the underdeveloped countries. According to him, there are two ways of explaining the inter-linkages among the bank credit and growth of domestic product. One of them is the Supply Leading Approach (SLA) and the other is the Demand Following Approach (DFA). Under SLA it is argued that credit behaves like one of the usual traditional inputs of production and so expansion of credit may lead to growth of domestic product of a country. On the other hand, under DFA, it is assumed that the financial development of a country is an offshoot of the development of the real sector. Alternatively it can be said that expansion of credit facility of a nation depends on its expansion of its infrastructure or growth of the domestic product. Patrick has proposed that the SLA is likely to hold in the early stages of development and at the later stage DFA is more likely. An appropriate link between the financial sector and real sector is required to have a balanced growth and development of a country as well as its regional levels particularly for the countries whose financial developments are not being saturated.

There exists a sizeable literature that deals with the positive impacts of financial sector in general and the banking sector in particular on the economic growth of a country. The study of Diamond (1984) has shown the positive role of bank finance on the allocation of capital by reducing the cost of capital by the process of delegated monitoring of the financial intermediary. In another study Greenwood and Jovanovic (1990) have explained the role of the finance on economic growth by the help of the endogenous growth theory. According to the study the financial sector collects and analyse the risk attached to the credit delivery and thereby allocate the financial capital at minimum costs and so helping the economic growth of a nation. The study of King and Levine (1993) has supported the Schumpeterian version of a positive and significant correlation between the financial sector and economic growth. Based on the study of 80 countries over the period 1960-89 they have established that various financial indicators like the ratio of credit allocated to private firms to GDP, the size of formal financial intermediation relative to GDP etc. have a strong and robust correlation with economic growth, rate of physical capital accumulation etc. Demetriades and Hussein (1996) have shown that there is a bilateral relationship between financial development and economic growth for a set of sixteen less developed countries. In another study of Jayaratne and Strahan (1996) on the states of USA provides evidence that financial markets can directly affect economic growth. It further provides that the rates of real, per capita growth in income and output increase significantly following intrastate branch reform. Improvements in the quality of bank lending, not increased volume of bank lending appear to be responsible for faster growth. Beck et al (2000) also highlight a positive correlation between development of financial intermediation and economic growth, rate of total factor productivity, savings rate and rate of physical capital accumulation. In a study on the state of Punjab in India, Sidhu, Vatta and Kaur (2008) estimated the contribution of institutional credit towards the use of production inputs, private investments and agricultural growth of the state. They showed that the relationship between the use of variable inputs and credit disbursement was highly significant suggesting that agricultural output growth was affected via access to production inputs.

In another study Kiran et al (2009) have shown that a long run relationship exists between financial development and economic growth for a panel of ten emerging countries including India for the period 1968-2007. In their effort, Eatzaz and Malik (2009) investigate the role of the of financial development on the growth of economy for the sample of thirty five developing countries and show that if the domestic bank credit to the private sector increased this would lead to increasing per workers output and consequently increasing the economic growth. In their discussion paper on the Indian economy, Bhanumurthy and Singh (2009) have shown that the high growth of Indian GDP has been due to financial inclusion, among others. They have shown that branch expansion is not the proper indicator of financial development. In contrary, the proper financial indicator is credit-deposit ratio. They observed that there has been cointegrated relation between credit-deposit ratio and State Domestic Product ratio. In a study specific to Indian states, Sehrawat and Giri (2015) examined the impact of financial development on growth of the 28 states for the period 1993- 2012. It revealed 
that there was causality from per capita credit as well as per capita deposits to economic growth. In another study, Narayanan (2015) examined the nature of the relationship between formal agricultural credit and agricultural GDP in India using state level panel data for the period 1995-96 to 2011-12. The findings from the analysis suggest that agriculture input use is sensitive to credit flow, whereas GDP of agriculture is not. Credit seemed therefore to be an enabling input for growth of agriculture as well as of the aggregate economy.

Ismail and Masih (2015) analyzed the finance-growth nexus in the context of the development of Islamic finance in Indonesia. The study finds a unique cointegrating relationship among GDP per capita, gross fixed capital formation, annual population growth rate, and domestic credit to private sector. In a detailed effort, Mohan and Ray (2017) described trends and turns of Indian financial system after crossing twenty five years of liberalization policy. It argues that there has been significant progress in making interest and exchange rates largely market determined during the reform phase leading to boost the growth rate of income, though the exchange rate regime remains one of managed float, and some interest rates remain administered.

In addition to all the above studies that support positive correlation between financial development and economic growth there are also studies that put forward reverse arguments on the association between these two components. Lucas (1988) did not find any association between economic growth and finance and he termed the relationship between financial and economic development as 'overstressed'. Demetriades and Luintel (1996) pointed out that the policy of financial liberalization followed by India had negative impact on growth as the effects of financial liberalization depended crucially upon institutional parameters like good governance that India did not have. In his work Sarkar (2009) has tried to examine whether financial development had any sort of influence on the growth of 65 developing economies including India during the period 1980-2006. Using dynamic panel data as well as individual country's data the study has concluded that there is negative causation from finance to growth and positive causation from growth to finance in the panel. However, using the individual country's data sets the study revealed that there is neither short term nor long term relationship between the two for the majority of the countries.

Recent researches have suggested that the level of financial development is good only up to a point, after which it becomes a haul on growth. This means that the relationship between finance and growth is a non-linear one or, more specifically an inverted U-shape. In their study, Cecchetti and Kharroubi (2013) find that for private sector credit extended by banks, the turning point is close to 90 per cent of GDP. They also find that the faster the financial sector grows, the slower the economy as a whole grows. This finding indicates that big and fast-growing financial sectors may be very costly for the rest of the economy in the sense that more financial sector's development exploits the existing resources of the economy. The innovative study of Law and Singh (2014) provides new evidence on the relationship between finance and economic growth using an innovative dynamic panel threshold technique for a sample of 87 developed and developing countries. The results indicate that there is a threshold effect in the finance-growth relationship in the way that up to a threshold point the level of financial development is beneficial to growth beyond which further development of financial sector tends to adversely affect growth. In their working paper on finance and economic growth in OECD and G20 countries, Cournède and Denk (2015) establish that finance has been a key ingredient of long-term economic growth in the countries over the past half-century, but indicate that at current levels of household and business credit further expansion slows rather than boosts growth. In a recent study on whether a country's level of economic development impacts its finance growth relationship for a panel of 90 countries from three different classes, Nguyena, Brown and Skully (2017) observed that the banking sector has a negative effect for all levels of development but more so for developed economies. Stock markets have a positive effect on growth for the middle income countries. It further shows that bond markets impacted growth positively for middle and high income countries whereas insurance provides a positive relationship to growth for all three groups of countries. In a technical report on the growth finance linkage for the high income countries, Benczúr, Karagiannis 
and Kvedaras (2017) show that the finding of a non-linear, hump-shaped impact of financing on economic growth is robust to controlling for financing composition in terms of the sources like bank credit, debt securities, stock market and the recipients of finances like households, non-financial and financial corporations, or both. In a recent study the study of Brei, Ferri and Gambacorta (2018) empirically investigates the link between financial structure and income inequality for a panel of 97 economies for 1989-2012. It reveals that, up to a point, more finance reduces income inequality, and beyond that point, inequality rises if finance is expanded via market-based financing, while it does not when finance grows via bank lending.

\section{Rationale of the Study}

The survey of literature briefs the finance-growth linkages at country levels in most cases without having the studies at the micro levels. The present study analyzes the short run and long run relationships between commercial bank credit and net real domestic products of the districts of West Bengal in India for the period 1993-2014, and tries the fill the gap in the literature.

The entire study has been organized as presenting the sections on data and methodology, analysis of results and conclusion.

\section{DATA AND METHODOLOGY}

In our target to examine the long run and short run linkages between financial development (which is proxied by bank credit) and real sector's development (proxied by district domestic product), we have used the Reserve Bank of India (RBI) data on district levels credit of the state of West Bengal (measured in Rupees lakh) provided by the commercial banks operating in India for the study period 1993-2014. The output data measured in net district domestic products (NDDP) at constant 1993-94 prices (measured in Rupees lakh) have been borrowed from different issues of the Bureau of Applied Economics and Statistics (BAES) of the Government of West Bengal. There are 18 undivided districts in our study which are namely Bankura, Bardhaman, Birbhum, Calcutta, Dakshin Dinajpur, Howrah, Hooghly, Jalpaiguri, Koch Bihar, Malda, Medinipur, Murshidabad, Nadia, North 24 Parganas, Purulia, South 24 Parganas, Uttar Dinajpur.

Since BAES publishes the data on NDDP at constant prices with different base years' prices, we have converted all the data for the period 1993-2014 in 1993-94 base prices to make the series in a single price deflated values. Further, as the data for the years 1994, 1995, and 2011, 2012 and 2013 are not available; we have interpolated them by augmenting them in the rate of annual average growth rates of NDDP for the remaining years across all the districts. Further, we have converted the current value data on credit into constant values in terms of 1993-94 prices. Further, as the data on population at district levels are not available for all the years, we could not convert the credit and NDDP into per capita levels. Hence, our credit and NDDP data are at aggregate levels; not in per capita levels.

Since we have 22 data points (published by the concerned authority available only for these periods) and studying long run and short run interlinkages between output and credit should be a priory preceded by testing for stationarity of the two series across all the selected districts. For a data set $\left(y_{t}, t=1,2, \ldots, T\right)$, where $t$ denotes time, let us consider the following linear regression set up for unit root test for two versions of the $\mathrm{ADF}(\mathrm{p})$ (1979) regression-viz:

$$
\Delta y_{t}=\alpha+\beta y_{t-1}+\sum_{j=1}^{p} \gamma_{j} \Delta y_{t-j}+u_{t}
$$

for the without time trend case and: 


$$
\Delta y_{t}=\alpha+\delta t+\beta y_{t-1}+\sum_{j=1}^{p} \gamma_{j} \Delta y_{t-j}+u_{t}
$$

for the with time trend case.

If $\beta=1$ is rejected by the $\mathrm{ADF}$ statistic then we say that the series is stationary. If this property holds for both the NDDP (y) and credit (x) series, then we can run regression without the chances of getting spurious regression results.

We have tested the existence of long run equilibrium relation between NDDP (the indicator for real sector) and credit (the indicator for financial sector) by Engel-Granger (1987) cointegration method and short run dynamics by Error Correction Mechanism (ECM) and Granger Causality (1969) analysis.

\section{Cointegration and Error Correction Mechanism}

Cointegration of two series gives the long run equilibrium relation between the two variables. The precondition to have the long run equilibrium relation is that the two series should be of I(1) so that their error term is $\mathrm{I}(0)$. Regression of an $\mathrm{I}(1)$ series of a variable upon another variable with $\mathrm{I}(1)$ series produces spurious results that is harmful to policy prescriptions. Engel and Granger (1987) offered a solution to this problem by introducing the concept of cointegration. If two series $\mathrm{Y}$ and $\mathrm{X}$ are both I(1) and are related by the following equation as:

$$
Y_{t}=\alpha+\beta X_{t}+u_{t}
$$

then their linear combination $u_{t}=Y_{t}-\alpha-\beta X_{t}$ will follow $\mathrm{I}(0)$ and both the series of $\mathrm{Y}$ and $\mathrm{X}$ will be cointegrated. Thus, a non-spurious long run relation between two series can be obtained by estimating the above equation (number) and then derive the estimated error term as $\hat{u}_{t}=Y_{t}-\hat{\alpha}-\hat{\beta} X_{t}$. If the series $\hat{u}_{t}$ is found to be $\mathrm{I}(0)$ or stationary then we can say that the series are cointegrated in EG sense. The estimated coefficients $\hat{\alpha}$ and $\hat{\beta}$ give us the long run equilibrium relation between $\mathrm{Y}$ and $\mathrm{X}$ whose form for $\mathrm{i}^{\text {th }}$ identity is:

$$
Y_{i t}=\hat{\alpha}+\hat{\beta} X_{i t}
$$

Testing stationarity of the estimated error term, $\hat{u}_{t}$, can be checked by the ADF test by estimating the following equation:

$$
\Delta \hat{u}_{t}=\hat{\phi u_{t-1}}+\sum_{i=1}^{j} \delta_{i} \hat{u}_{t-i}+\varepsilon_{t}
$$

We then test for whether $\phi=1$ against $\phi<1$. If the hypothesis of $\phi=1$ is rejected then we say that $\mathrm{Y}$ and $\mathrm{X}$ are cointegrated series and there exists an equilibrium long run relation between them.

Existence of long run equilibrium relation between two series does not necessarily mean that there do not have short run deviations from the equilibrium relation. Such deviations are called errors. We thus need to test whether these errors get corrected or they move back to the equilibrium long run relation. If they converge to the equilibrium then we say errors are corrected and if they diverge from 
the equilibrium then we say errors are not corrected. We can model this short run dynamics vis-à-vis the long run relation by the Error Correction Mechanism (ECM). The ECM can be written as follows:

$\Delta Y_{i t}=a+\eta \Delta X_{i t}+\gamma \hat{u}_{t-1}+e_{t}$

Here $\hat{u}_{t-1}$ stands for the error correction term. If the estimated $\gamma$ is found to be negative and significant then we say that the series is converging and the short run deviations are wiped out. On the other hand, if the estimated $\gamma$ is found to be positive and significant then we say that the series is diverging and the series are going away from the long run equilibrium relation. The above equation represents the short run relation between the variables and $\eta$ stands for short run regression coefficient whose values have been given in the table (number).

\section{Granger Causality Test}

For a bivariate model with both the series as non stationary and integrated of order one for all the districts the Granger causality test is done by estimating the following equations in first difference form of the variables including the error correction terms for $y$ on $x$ and $x$ on $y$ (Granger, 1969). The equations are:

$\Delta y_{t}=\nu_{y x}+\sum_{j=1}^{T_{11}} \alpha_{1 j} \Delta y_{t-j}+\sum_{j=1}^{T_{12}} \beta_{1 j} \Delta x_{t-j}+\eta_{y x} E C Y_{t-1}+u_{1 t}$

$\Delta x_{t}=\nu_{x y}+\sum_{j=1}^{T_{21}} \alpha_{2 j} \Delta y_{t-j}+\sum_{j=1}^{T_{22}} \beta_{2 j} \Delta x_{t-j}+\eta_{x y} E C X_{t-1}+u_{1 t}$

Here $\Delta$ denotes the first difference operator; $T_{l m}, l, m=1,2$ denotes the number of lagged values of $\Delta y$ and $\Delta x$ that affect the current values of these differenced variables; $\nu, \alpha, \beta$ and $\eta$ denote regression parameters; $u_{l t,} l=1,2$ are the equation disturbance terms with white noise properties. The parameters $\eta_{y x}$ and $\eta_{x y}$ in Equations (7) and (8) are called the adjustment parameters which are to be negative and significant to justify the error correction feature. $\mathrm{ECY}_{\mathrm{t}-1}$ and $\mathrm{ECX}_{\mathrm{t}-1}$ respectively represent the error correction terms obtained from residuals of the regressions of $\mathrm{Y}$ on $\mathrm{X}$ and $\mathrm{X}$ on Y. In this present set up the nature or direction of Granger Causality is determined by the values of the F statistics where the judgments are as follows:

1. If $\beta_{l j}=0$, for all $j$ and $\eta_{y x}=0, x$ may be said not to Granger cause $y$.

2. If $\alpha_{2 j}=0$ for all $j$ and $\eta_{x y}=0, y$ may be said not to Granger cause $x$.

3. If (1) holds but (2) does not, Granger causality may be said to be unidirectional from y to $x$.

4. Conversely, if (1) does not hold but (2) does, Granger causality may be said to be unidirectional from $x$ to $y$.

5. If both (1) and (2) do not hold, Granger causality between $x$ and $y$ may be said to be bi-directional or feedback causality.

6. If both (1) and (2) hold, there is no Granger causality between $x$ and $y$. 


\section{ANALYSIS OF RESULTS}

Before going into the quantitative assessment of our hypothesis of examining the short run and long run relationships between districts' credits and NDDPs in the state of West Bengal in India, let us have a graphical view of the logarithmic values of the two series. Figure 1 and 2 respectively present the charts for logcredit and $\log$ NDDP of the districts for the study period.

It is observed from Figure 1 that all the series of logcredit are upward rising over time. Calcutta holds the top position in credit level which is well above the levels of the follower districts like Bardhaman, N. 24 Parganas and Medinipur. The district of D. Dinajpur is in the trough of the entire series of credit. Nadia, Jalpaiguri, S. 24 Parganas are the districts staying in the middle position.

We observe from Figure 2 that all the series of the districts' $\operatorname{logNDDP}$ are of increasing trends. The district of Medinipur leads the group before 2005 followed by N. 24 Parganas, Calcutta and Bardhaman. In 2005, Medinipur and N. 24 Parganas coincide in the district output level and after that the former slips down to second position and the latter occupy the first position. Bardhaman follows Medinipur and Calcutta slips down to fourth position. D. Dinajpur holds the $18^{\text {th }}$ rank for the entire period in terms of district output like bank credit.

Figure 1. District wise series for Logcredits

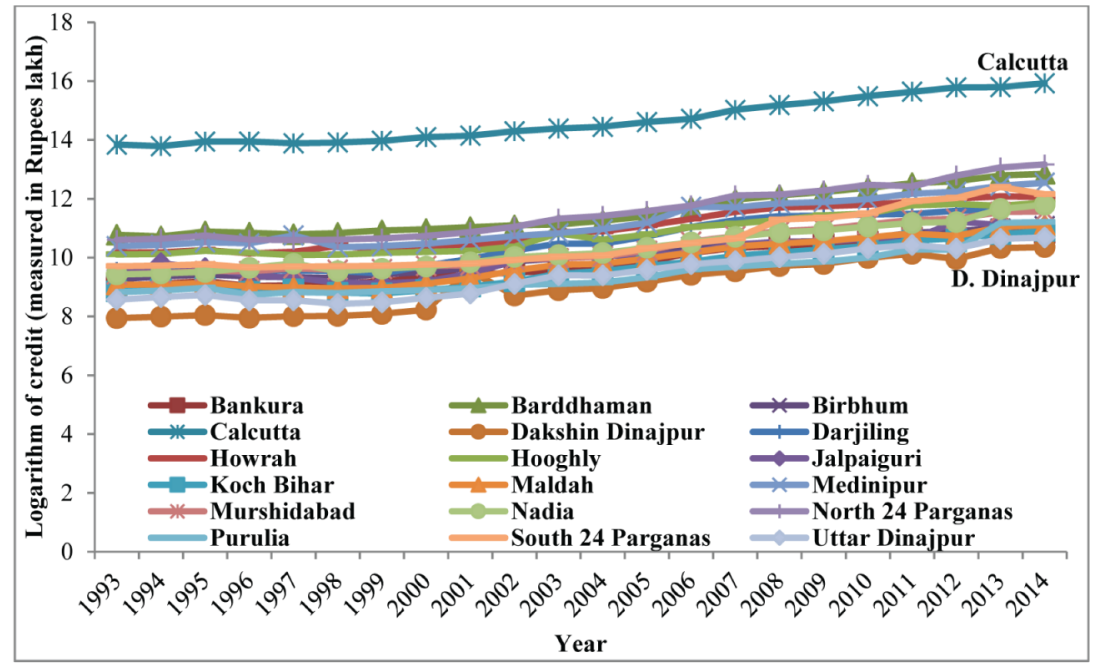

Source: Sketched by the authors on the basis of the data of BAES, West Bengal

\section{Unit Root Test Results}

We have computed the ADF test statistics for logcredit and logNDDP series for all the districts by estimating equation ( 1 and 2 ). The results are presented in Table 1 . We have observed that both the series are non stationary at levels and they suffer from unit root problem. We, thus, do not show this in the table. But all the logNDDP series are stationary at their first differences (or they are I(1) series) except Malda, Murshidabad and Nadia. The logNDDP series of these three districts are stationary at their second differences or they are I(2) series. The series for Bankura and D. Dinajpur are weakly stationary as the probability values are greater than 0.05 and less than 0.10 . 
Figure 2. District wise series for LogNDDP

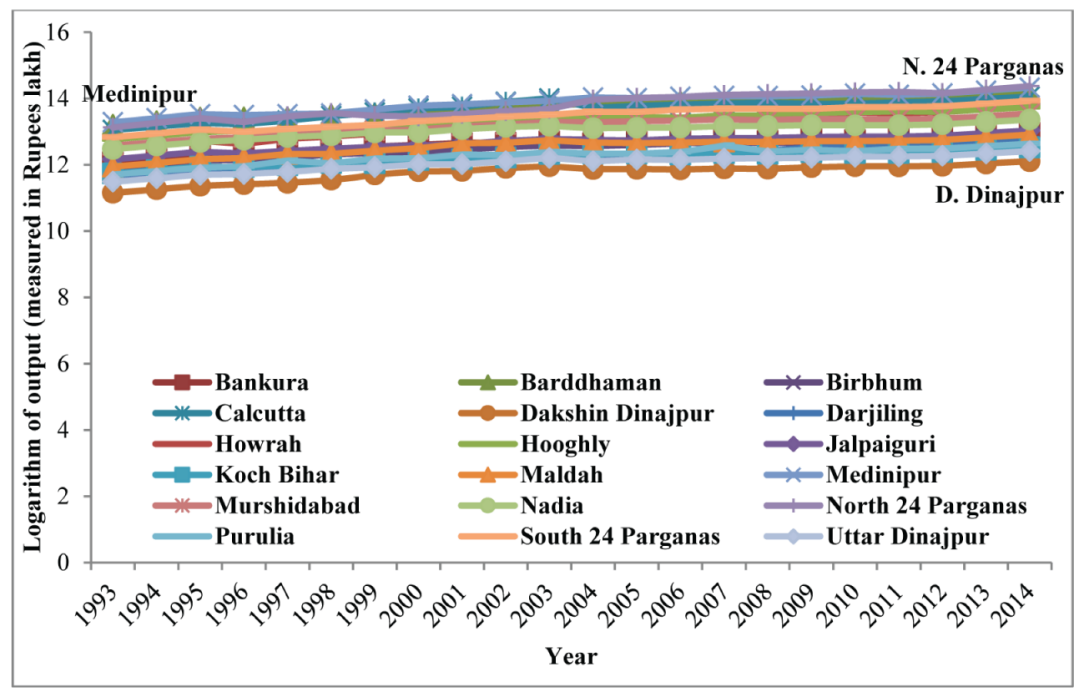

Source: Sketched by the authors on the basis of the data of BAES, West Bengal

Table 1. Unit roots test results for logNDDP and logcredit

\begin{tabular}{|c|c|c|c|c|c|c|c|c|}
\hline \multicolumn{5}{|c|}{ NDDP at First Differences } & \multicolumn{4}{|c|}{ Credit at First Differences } \\
\hline Districts & ADF & Lag & Prob & Remarks & ADF & Lag & Prob & Remarks \\
\hline Bankura & -2.979634 & 1 & .08 & $\mathbf{S}$ & -3.468950 & 1 & 0.0204 & $\mathbf{S}$ \\
\hline Bardhaman & -5.300861 & 1 & 0.01 & $\mathbf{S}$ & -3.156724 & 1 & 0.0383 & $\mathbf{S}$ \\
\hline Birbhum & -3.388572 & 1 & 0.05 & $\mathbf{S}$ & -2.993429 & 1 & 0.0527 & $\mathbf{S}$ \\
\hline Kolkata & -3.216835 & 1 & 0.05 & $\mathbf{S}$ & -3.869480 & 1 & 0.0088 & $\mathbf{S}$ \\
\hline Darjeeling & -5.475901 & 1 & 0.01 & $\mathbf{S}$ & -2.927338 & 1 & 0.0598 & $\mathbf{S}$ \\
\hline D.Dinajpur & -2.751500 & 1 & 0.09 & $\mathbf{S}$ & -7.065185 & 1 & 0.0000 & $\mathbf{S}$ \\
\hline Howrah & -4.108040 & 1 & 0.01 & $\mathbf{S}$ & -3.715719 & 1 & 0.0122 & $\mathbf{S}$ \\
\hline Hooghly & -3.626052 & 1 & 0.05 & $\mathbf{S}$ & -5.055087 & 1 & 0.0007 & $\mathbf{S}$ \\
\hline Jalpaiguri & -4.445340 & 1 & 0.01 & $\mathbf{S}$ & -4.129357 & 1 & 0.0050 & $\mathbf{S}$ \\
\hline Koch Bihar & -3.381875 & 1 & 0.05 & $\mathbf{S}$ & -2.769384 & 1 & 0.0805 & $\mathbf{S}$ \\
\hline Malda & -4.808386 & 1 & 0.01 & $S 2^{\text {nd }} \operatorname{diff}$ & -3.389372 & 1 & 0.0240 & $\mathbf{S}$ \\
\hline Medinipur & -3.755756 & 1 & 0.05 & $\mathbf{S}$ & -4.899364 & 1 & 0.0010 & $\mathbf{S}$ \\
\hline Murshidabad & -5.237526 & 1 & 0.01 & $S 2^{\text {nd }} \operatorname{diff}$ & -3.605471 & 1 & 0.0153 & $\mathbf{S}$ \\
\hline N 24 Parganas & -4.078347 & 1 & 0.01 & $\mathbf{S}$ & -3.705475 & 1 & 0.0124 & $\mathbf{S}$ \\
\hline Nadia & -4.201471 & 1 & 0.01 & $S 2^{\text {nd }}$ diff & -4.364617 & 1 & 0.0031 & $\mathbf{S}$ \\
\hline Purulia & -3.305458 & 1 & 0.05 & $\mathbf{S}$ & -4.338416 & 1 & 0.9016 & $S 2^{\text {nd }}$ diff \\
\hline S 24 Parganas & -3.710215 & 1 & 0.05 & $\mathbf{S}$ & -4.006242 & 1 & 0.0066 & $\mathbf{S}$ \\
\hline U. Dinajpur & -3.180386 & 1 & 0.05 & $\mathbf{S}$ & -3.752637 & 1 & 0.0113 & $\mathbf{S}$ \\
\hline
\end{tabular}

Note: $2^{\text {nd }}$ diff. means the series are stationary at second differences.

Source: Computed by the authors on the basis of the data of BAES, West Bengal. 
On the other hand, all the logcredit series are stationary at their first differences (or they are I(1) series) except only Purulia which is integrated of order 2. Koch Bihar is the district whose NDDP series is $\mathrm{I}(1)$ in weak sense since $0.05<\mathrm{p}<0.10$.

\section{Cointegration and Error Correction Results}

Combining the results of unit root tests for logcredit and $\log$ NDDP series we find that the series for Malda, Murshidabad, Nadia and Purulia are I(2) and all the remaining 14 districts' series are I(1) for both the variables. We have, therefore, run the EG cointegration test for these 14 districts as there are the possibilities of long run equilibrium relations and for the remaining 4 districts we have not run the same test procedure. At the same time we have examined short run dynamics for the conitegrated series of the districts by means of error correction mechanism by estimating equation 6 . The results of cointegration test and error corrections have been presented in Table 2 following the estimation of equation 4,5 and 6.

We have first run regression of $\operatorname{logNDDP}$ upon logcredit to find the long run (LR) relation between the two variables. Column 2 and 3 of Table 2 depict the estimated values of the constants and regression coefficients signifying the credit elasticity of output. The highest credit elasticity is observed for Howrah with the value 0.473 followed by N. 24 Parganas and the lowest is for Koch Bihar which is 0.24 . After that, we have estimated the residuals and tested their stationarity. The results of stationarity of the estimated residuals as well as the existence of cointegration have been presented in last column of the table. Out of the 14 districts with the $\log$ NDDP and logcredit series as I(1), all the districts except only Bardhaman depict the existence of cointegration between the output and credit. That means, except Bardhaman, Malda, Murshidabad, Nadia and Purulia, there are long run equilibrium relation between credit and output. More specifically we can say that there are linkages between the financial sector and real sector of these 13 districts.

In the next step, we have examined the short run dynamics along these cointegrtaed series. In other way to say, whether there have been errors in the short run and whether they got corrected (or converged) or not (or diverged). The results of error corrections have been given in column 5 of Table 2. It is observed that all the error correction terms for the 13 districts are of usual negative signs (that is the signs of convergence) but they are corrected in 10 districts; Howrah, Medinipur and S. 24 Parganas are the districts with no corrections of errors as their probability values are well above the 5\% levels. The highest rate of convergence is observed for N. 24 Parganas (33\%) and lowest rate for Jalpaiguri (16\%).

By incorporating the error correction terms into the short run regression equation (6) we compute the short run credit elasticity of output across the districts and the results are presented in column 4 of Table 2 . We observe relatively lower values of the elasticity across the districts compared to that of the long run results. In case of D. Dinajpur and S. 24 Parganas, the elasticity signs are negative meaning credit hinders their NDDP levels.

\section{Granger Causality Test Results}

We now analyze another part of the short run dynamics by incorporating the error correction terms to examine whether there exist causal relations between credit and NDDP in first and second differences wherever applicable. We have done this by Granger Causality Test by estimating equation 7 and 8 . It is to note here that there can be causal relation even the series are not cointegrated. The hypotheses of the model are as follows:

Model I: Credit does not cause NDDP.

Model II: NDDP does not cause Credit.

The results of causality test have been offered in Table 3. We observe five cases of unilateral causality where NDDP make a cause to credit (the districts are Bankura, Bardhaman, Birbhum, 
Table 2. EG Cointegration test and error correction results

\begin{tabular}{|c|c|c|c|c|c|c|}
\hline Districts & $\begin{array}{l}\text { Regr. } \\
\text { Const }\end{array}$ & $\begin{array}{c}\text { Regr. } \\
\text { Coeff(LR) }\end{array}$ & $\begin{array}{c}\text { Regr. } \\
\text { Coeff(SR) }\end{array}$ & EC term(prob) & $\begin{array}{c}\text { DW } \\
\text { for } \\
\text { ECM }\end{array}$ & $\begin{array}{c}\text { Remarks } \\
\text { Whether } \\
\text { Cointegration is } \\
\text { Present }\end{array}$ \\
\hline Bankura & 9.65 & 0.302 & 0.08 & $\begin{array}{c}-0.208(0.03) \text { errors } \\
\text { corrected }\end{array}$ & 1.84 & Yes \\
\hline Bardhaman & 9.87 & 0.33 & - & - & & No \\
\hline Birbhum & 8.77 & 0.36 & 0.122 & $\begin{array}{c}-0.182(0.05) \text { errors } \\
\text { corrected }\end{array}$ & 1.54 & Yes \\
\hline Calcutta & 9.16 & 0.308 & 0.09 & $\begin{array}{c}-0.180(0.09) \text { errors } \\
\text { corrected }\end{array}$ & 1.82 & Yes \\
\hline Darjeeling & 8.35 & 0.367 & 0.122 & $\begin{array}{c}-0.28(0.09) \text { errors } \\
\text { corrected }\end{array}$ & 2.01 & Yes \\
\hline D.Dinajpur & 9.44 & 0.25 & -0.009 & $\begin{array}{c}-0.14(0.09) \text { errors } \\
\text { corrected }\end{array}$ & 1.98 & Yes \\
\hline Howrah & 7.98 & 0.473 & 0.106 & $\begin{array}{c}-0.11(0.28) \\
\text { Not corrected }\end{array}$ & 2.14 & Yes \\
\hline Hooghly & 9.22 & 0.379 & $0.14(0.06)$ & $\begin{array}{l}-0.18(0.05) \\
\text { errors corrected }\end{array}$ & 1.90 & Yes \\
\hline Jalpaiguri & 9.77 & 0.288 & 0.06 & $\begin{array}{l}-0.16(0.03) \\
\text { errors corrected }\end{array}$ & 1.78 & Yes \\
\hline Koch Bihar & 9.85 & 0.243 & 0.17 & $\begin{array}{c}-0.21(0.02) \text { errors } \\
\text { corrected }\end{array}$ & 1.53 & Yes \\
\hline Malda & $\begin{array}{l}\text { Second } \\
\text { diff }\end{array}$ & & & & & - \\
\hline Medinipur & 10.07 & 0.338 & 0.03 & $\begin{array}{c}-0.09(0.28) \text { Not } \\
\text { corrected }\end{array}$ & 1.52 & Yes \\
\hline Murshidabad & $\begin{array}{l}\text { Second } \\
\text { diff }\end{array}$ & & & & & - \\
\hline N 24 Parganas & 9.07 & 0.409 & 0.15 & $\begin{array}{l}-0.33(0.03) \\
\text { errors corrected }\end{array}$ & 1.89 & Yes \\
\hline Nadia & $\begin{array}{l}\text { Second } \\
\text { diff }\end{array}$ & & & & & - \\
\hline Purulia & $\begin{array}{l}\text { Second } \\
\text { diff }\end{array}$ & & & & & - \\
\hline S 24 Parganas & 10.45 & 0.284 & -0.04 & $\begin{array}{c}-0.06(0.35) \\
\text { Not corrected }\end{array}$ & 2.28 & Yes \\
\hline U. Dinajpur & 9.47 & 0.272 & $0.15(0.06)$ & $\begin{array}{l}-0.19(0.02) \\
\text { errors corrected }\end{array}$ & 1.73 & Yes \\
\hline
\end{tabular}

Source: Computed by the authors using Eviews

Note: The stationarity tests for the estimated error terms to justify the existence of cointegrations between NDDP and Credit for the districts have been checked in three testing options of 'none', 'intercept' and 'intercept and trend'. The mentioned results of the existence of cointegration (in the Remarks column) fall in any of the three options. We have not mentioned the DW values in cases where there are no cointegration results. LR means long run, SR means short run and EC means error correction.

Calcutta and Koch Bihar) and four cases where credit make a cause to NDDP (the districts are Darjiling, Howrah, Purulia and U. Dinajpur). In all the remaining nine districts, we don't find any sort 
Table 3. Granger causality test results

\begin{tabular}{|c|c|c|}
\hline Districts & Lags & Directions of Causality \\
\hline Bankura & 3 & $\Delta \mathrm{NDDP} \rightarrow \Delta$ Credit \\
\hline Bardhaman & 1 & $\Delta \mathrm{NDDP} \rightarrow \Delta$ Credit \\
\hline Birbhum & 1 & $\Delta \mathrm{NDDP} \rightarrow \Delta$ Credit \\
\hline Calcutta & 1 & $\Delta \mathrm{NDDP} \rightarrow \Delta$ Credit \\
\hline Darjeeling & 1 & $\Delta$ Credit $\rightarrow \Delta$ NDDP \\
\hline D.Dinajpur & Up to 3 & No \\
\hline Howrah & 1 & $\Delta$ Credit $\rightarrow \Delta$ NDDP \\
\hline Hooghly & Up to 3 & No \\
\hline Jalpaiguri & Up to 3 & No \\
\hline Koch Bihar & 1 & $\Delta \mathrm{NDDP} \rightarrow \Delta$ Credit \\
\hline Malda & Up to 3 & No at $2^{\text {nd }}$ diff. series \\
\hline Medinipur & Up to 3 & No \\
\hline Murshidabad & Up to 3 & No at $2^{\text {nd }}$ diff. series \\
\hline N 24 Parganas & Up to 3 & No \\
\hline Nadia & Up to 3 & No at $2^{\text {nd }}$ diff. series \\
\hline Purulia & 3 & $\Delta^{2}$ Credit $\rightarrow \Delta^{2}$ NDDP at $2^{\text {nd }}$ diff. series \\
\hline S 24 Parganas & Up to 3 & No \\
\hline U. Dinajpur & 2 & $\Delta$ Credit $\rightarrow \Delta$ NDDP \\
\hline
\end{tabular}

Source: Computed by the authors using Eviews

of causations from either ends of the variables. That means, for five districts, we observe the demand following approach to work and for four districts, there are the workings of supply leading approach.

Hence, the present study follows the Schumpeterian $(1911,1934)$ line of thinkers that financial sector and the real sectors should have inter linkages so far as the long run test results are concerned in general and the study of Bhanumurthy and Singh (2009) in particular. Further, the short run analysis partially fulfills the claim of Patrick (1966) as there are only five districts that produce demand following results. But most of the districts do not produce either of the linkage effects in the short runs that follow the results of Sarkar (2009).

\section{CONCLUSION}

In studying whether there are long run equilibrium relation and short run causations between commercial bank credit and net real district domestic products across the eighteen districts of the state of West Bengal in India for the period 1993-2014, we arrive now in a conclusion that, having non stationary property at levels and stationary at first and second differences of the two series, there are eleven districts which produce the results of the existence of the long run equilibrium relation between credit and output and in most of the cases the errors are corrected. That means, bank credit as the financial indicator and net district domestic product as the real sector's indicator has long run associations and they move side by side over time. Further, the short run dynamics show that there are five districts namely Bankura, Bardhaman, Birbhum, Calcutta and Koch Bihar where output make a cause to bank credit and in four districts, namely, Darjiling, Howrah, Purulia and U. Dinajpur, where credit make a cause to output. The remaining eleven districts do not produce any direction of 
causality between the two variables. This means, financial indicator and real sector's indicator have limited causality which appear in the short term. It may further be concluded that there may be other factors besides credit or output that make significant influence upon either of the two variables to work. The financial and real sectors should think of strengthening the developments of these two sectors so that there can be appropriate linkages between credit and output at district levels to signify the effect in entire state as well as to the whole country. 


\section{REFERENCES}

Beck, T., Levine, R., \& Loayza, N. (2000). Finance and the Sources of Growth. Journal of Financial Economics, 58(1-2), 261-300. doi:10.1016/S0304-405X(00)00072-6

Benczúr, P., Karagiannis, S., \& Kvedaras, V. (2017). Finance and economic growth: financing structure and non-linear impact. European Commission, Joint Research Centre, JRC Technical Report, October.

Bhanumurthy, N. R., \& Singh, P. (2009). Understanding Economic Growth in Indian States; a discussion paper. Institute of Economic Growth.

Brei, M., Ferri, G., \& Gambacorta, L. (2018). Financial structure and income inequality. BIS Working Papers No 756, Monetary and Economic Department, Basel, Switzerland.

Cecchetti, G. \& Kharroubi, E., (2013). Why does Financial Sector Growth Crowd out Real Economic Growth? Finance and the Wealth of Nations Workshop, Federal Reserve Bank of San Francisco \& The Institute of New Economic Thinking.

Cournède, B., \& Denk, O. (2015). Finance and economic growth in OECD and G20 countries. OECD Economics Department Working Paper, No. 1223, ECO/WKP (2015)41.

Demetriades, P. O., \& Hussein, K. (1996). Does Financial Development causes Economic Growth? Time Series Evidence from Sixteen Countries. Journal of Development Economics, 51(2), 387-411. doi:10.1016/S03043878(96)00421-X

Demetriades, P. O., \& Luintel, K. B. (1996). Financial Development, Economic Growth and Banking Sector Control, Evidence from India. Economic Journal (London), 106(435), 359-374. doi:10.2307/2235252

Diamond, D. (1984). Financial intermediation and delegated monitoring. The Review of Economic Studies, 51(3), 393-414. doi:10.2307/2297430

Dickey, D. A., \& Fuller, W. A. (1979). Distribution of the estimators for autoregressive timeseries with a unit root. Journal of the American Statistical Association, 74.

Eatzaz, A., \& Malik, A. (2009). Financial Sector and Economic Growth: An Empirical Analysis of Developing Countries. Journal of Economic Cooperation and Development, 30(1), 17-40.

Engle, R. F., \& Granger, C. W. (1987). Co-integration and error correction: Representation, estimation and testing. Econometrica, 55(2), 55. doi:10.2307/1913236

Granger, C. W. J. (1969). Investigating causal relations by econometric models and cross spectral methods. Econometrica, 37(3), 424. doi:10.2307/1912791

Greenwood, J., \& Jovanovich, B. (1990). Financial Development, Growth and the Distribution of Income. Journal of Political Economy, 98(5, Part 1), 1076-1107. doi:10.1086/261720

Ismail, M. A. M., \& Masih, M. (2015). Causality between financial development and economic growth, and the Islamic finance imperative: A case study of Indonesia. INCEIF.

Jayaratne, J., \& Strahan, P. E. (1996). The finance-growth nexus: Evidence from bank branch deregulation. The Quarterly Journal of Economics, 111(3), 639-670. doi:10.2307/2946668

King, R. G., \& Levine, R. (1993). Finance and Growth: Schumpeter Might Be Right. The Quarterly Journal of Economics, 108(3), 717-738. doi:10.2307/2118406

Kiran, B., Yavuz, N. C., \& Guris, B. (2009). Financial Development and Economic Growth: A Panel Data Analysis of Emerging Countries. International Research Journal of Finance and Economics, 30, 87-94.

Law, S., \& Singh, N. (2014). Does Too Much Finance Harm Economic Growth? Journal of Banking \& Finance, 41(C), 36-44. doi:10.1016/j.jbankfin.2013.12.020

Lucas, R. E. Jr. (1988). On the Mechanics of Economic Development. Journal of Monetary Economics, 22(1), 3-42. doi:10.1016/0304-3932(88)90168-7 
Mohan, R., \& Ray, P. (2017). Indian Financial Sector: Structure, Trends and Turns. IMF Working Paper, Asia and Pacific Department, No. WP/17/7.

Narayanan, S. (2015). The Productivity of Agricultural Credit in India. Indira Gandhi Institute of Development Research, Mumbai, Working Paper, January, No. WP-2015-01.

Nguyena, Y. N., Brown, K., \& Skully, M. (2017). Economic Development Levels and the Finance and Growth Nexus. Paper presented at the 2014 Paris Financial Management Conference, Monash University, Australia.

Patrick, H. T. (1966). Financial Development and Economic Growth in UDCs. Economic Development and Cultural Change, 14, 174-189. doi:10.1086/450153

SarkarP. (2009). Does Finance Matter for Growth? What the data Show? Available at SSRN: www.ssrn.com/ abstract $=951013 \quad 10.2139 /$ ssrn. 951013

Schumpeter, J. (1911). The Theory of Economic Development. Harvard University Press.

Schumpeter, J. A. (1934). The Theory of Economic Development: An Inquiry into Profits, Capital, Credit, Interest, and the Business Cycle. Transaction Publishers.

Sehrawat, M., \& Giri, A. K. (2015). The Role of Financial Development in Economic Growth: Empirical Evidence from Indian States. International Journal of Emerging Markets, 10(4), 765-780. doi:10.1108/ IJoEM-05-2014-0064

Sidhu, R. S., Vatta, K., \& Kaur, A. (2008). Dynamics of Institutional Agricultural Credit and Growth in Punjab: Contribution and Demand-Supply Gap. Agricultural Economics Research Review, 21, 407-414.

Smith, A. (1789). An Inquiry into the Nature and Causes of the Wealth of Nations (5th ed.). Academic Press.

Ramesh Chandra Das is currently Associate Professor of Economics at Vidyasagar University, Midnapore, West Bengal, India. He has obtained Masters, M. Phil and Ph. D Degree in Economics from the University of Calcutta. He has eighteen years of teaching and research experience in different fields of economics including theoretical and empirical economics, financial economics, environmental economics and political economics. Dr. Das has contributed several research papers to national and international journals and completed three MRPs sponsored by UGC, India. He has one text book on Microeconomics for different fields of readers and academician. He is the editor-in-chief in Asian Journal of Research in Business Economics and Management, Associate Editor of International Journal of Research on Social and Natural Sciences and one of the EAB members of Society for the Study on Business and Finance. He edited two Handbooks on Globalization, Investment and Growth-Implications of Confidence and Governance and Global Indicators of Economic and Political Convergence and two edited volumes on Infrastructure developments, and worked as guest editor of IJSEM's Special Issue (2 parts), all are of IGI Global, USA.

Bankim Ghosh is presently assistant professor in Economics at Katwa College, WB, India with three years of teaching experience. His research interests lie in Agricultural Economics, Human Development and Development Economics. 